ELORE (ISSN 1456-3010), vol. $12-1 / 2005$.

Julkaisija: Suomen Kansantietouden Tutkijain Seura ry.

Toimittaneet: Outi Fingerroos ja Kaarina Koski. Taitto: Jukka Talve.

[http://cc.joensuu.fi/ /oristi/1_05/jyl1_05.pdf]

\title{
KIPU JA KUOLEMA
}

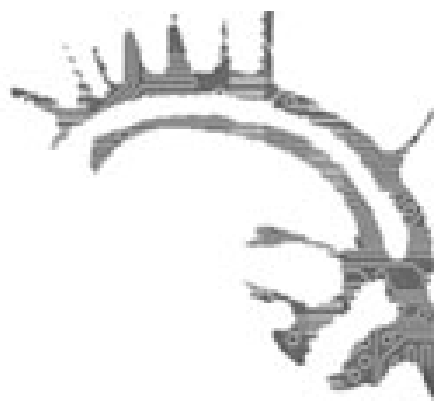

Kärsimyksen representaatioita suomalaisessa eutanasiapuheessa

Leila Jylhänkangas

Biologisessa mielessä kuolema tekee lopullisen eron kuolevan ja elävien välille. Kenties juuri siksi kuolemaa koskevat pohdinnat ovat mukana myös nykyihmisen ajatuskartalla, vaikka lääketieteen teknologian ja elinsiirtojen avulla kuolemaa on voitukin siirtää tuonnemmaksi (ks. elinsiirroista esim. Huhtamies \& Relander 1997). Missään kulttuurissa elämän ja kuoleman välisen rajan ylittämistä ei nähdä vain välttämättömänä biologisena tapahtumana, vaan se yritetään tehdä käsitettäväksi ja hallittavaksi erilaisten kulttuurisidonnaisten ymmärtämisen tapojen ja rituaalien avulla (Anttonen 1999, 11-12; Boyer 2001, 203-210). Myös kuolemaan usein liittyvää kipua ja kärsimystä merkityksellistetään kulttuurissa eri tavoin.Elämän loppuvaiheen kärsimykset antavat usein kimmokkeita ajatukselle kuoleman jouduttamisesta, eutanasiasta (ks. määritelmä jäljempänä). Tarkastelen tässä artikkelissa kärsimystä ihmisruumiiseen kytkeytyvänä kulttuurisena merkityksenannon kohteena suomalaisessa eutanasiapuheessa. Aineistoni koostuu suomalaisten yksityishenkilöiden kirjoittamista, eutanasiaan kantaaottavista kirjeistä, jotka olen kerännyt suomalaisissa sanoma- ja aikakauslehdissä vuosina 2000-2001 julkaistuin kirjoituspyynnöin (1). Artikkelissani tarkastelen näiden kirjeiden valossa kuolemiseen liittyvän kärsimyksen ja siihen kietoutuvan kivun representaatioita ja niiden suhdetta erilaisiin eutanasiakannanottoihin.

Eutanasiaan suhtautuminen voi olla torjuvaa, hyväksyvää tai keinuvaa, mitkä olen kirjeaineistoa luettuani nimennyt eutanasiapuheen toistuviksi ulottuvuuksiksi (ks. myös Jylhänkangas 2004). Näissä kirjeissä tehdään paljon arvoladattuja rajanvetoja paitsi elämän ja kuoleman myös terveyden ja sairauden välille. Artikkelini alussa pohdin eutanasiapuheen lukemisen rajoja: "Kuinka kirjeaineistoa on mahdollista lukea?" Lisäksi tarkastelen, millainen asema kulttuurisilla kategorioinneilla ja niitä ilmentävillä metaforilla on eutanasiapuheessa. Kysyn myös, kuinka kipu ja kärsimys kietoutuvat eutanasiapuheessa toisiinsa. Näihin liittyen nostan esille hyväksyttävinä ja arvokkaina pidettyjen kuolemisen tapojen representaatioita eutanasiapuheessa. Eutanasian hyväksyvän puheen osalta tarkastelen toimivan ja toimimattoman ihmisruumiin väliseen rajanvetoon liitettyjä merkityksiä. Pohdin artikkelissani myös sitä, kuinka eutanasiapuhetta motivoivat sellaiset kulttuuriset ja 


\section{LEILA JYLHÄNKANGAS}

uskonnolliset merkityksenannot, joiden ytimessä ovat kulttuuristen kategoriaerottelujen erilaiset painotukset ja vaihtelut (ks. Anttonen 1997).

\section{EUTANASIAN MÄÄRITTELY}

Eutanasian alkuperäinen merkitys (kreik. eu + thanatos = 'hyvä kuolema') liittyi kuolevista huolehtimiseen ja näiden auttamiseen kivuttomaan mutta luonnolliseen kuolemaan (Pahlman 2003, 205). Lääketieteessä eutanasialla tarkoitetaan lääkärin osallisuutta tilanteessa, joka aiheuttaa potilaan kuoleman. Eutanasiasta on käytetty myös ilmaisua aktiivinen kuolinapu (Nissilä 1999, 419). (2) Eri käsitteitä käytettäessä viitataankin tavallisimmin juuri eutanasian aktiiviseen muotoon, jossa kuolemaa joudutetaan lääketieteellisten toimenpiteiden avulla. Joudutetun kuoleman vastakohta on pitkitetty elämä, dystanasia, joskin molemmissa on kysymys kuoleman ajankohtaan puuttumisesta. Kun elämän loppuvaiheen hoitoratkaisuna on dystanasia, seurauksena voi olla myös kärsimyksen pitkittäminen ja epäinhimillistäminen. (Nissilä 1999, 419.)

Eutanasia-käsitteen monimerkityksisyydestä (ks. Korhonen 1994, 62-65) johtuen osuvinta on ehkä käyttää ilmaisua aktiivinen kuolinapu (Nissilä 1999, 419) tai joudutettu kuolema. Toisaalta eutanasia on laajasti käytetty käsite, johon liitetyt mielleyhtymät rakentuvat erilaisissa konteksteissa; kyse voi olla yhtä hyvin lääketieteellisestä asiantuntijatiedosta kuin maallikkoajattelusta. Aktiivisen kuolinavun lisäksi eutanasiasta käytetään joskus nimityksiä armomurha ja armokuolema. Puhujien käyttämät kielikuvat kertovat niistä arvoladatuista kategorioista, joilla paitsi elämää myös hyväksyttävinä tai torjuttavina pidettyjä kuolemisen tapoja määritetään. Kuolemaan liittyvät kulttuuriset kategoriat ja metaforat ilmaisevat kulttuurista tietoa kuolemasta. (Jylhänkangas 2004, 328-341.)

Viime kädessä sekä eutanasian että dystanasian tarkoituksena on yritys ballita kuolemaa vaikuttamalla sen ajankohtaan - joko jouduttamalla tai siirtämällä sitä tuonnemmaksi. Eutanasiapuheessa otetaan kantaa ja pohditaan näitä molempia. Kulttuurintutkijan tehtävää ajatellen on mielenkiintoista huomata, kuinka eutanasiapuhetta sävyttävät usein juuri kulttuuriset ja uskonnolliset merkityksenannot.

\section{EUTANASIAPUHEEN LUKEMISEN RAJAT}

Eutanasiaa käsittelevien kirjeiden lukeminen ei ole ongelmatonta, sillä kuolemaa koskevat jäsennykset ovat eri kirjoittajilla erilaisia. Yksittäinen kirje ei myöskään sisällä kaikkea sitä tietoa, mitä tekstin kirjoittanut henkilö kantaa mielessään. Aineisto on tuotettu tiettynä aikana ja tietyssä paikassa, joten teksti ei sellaisenaan ole suora peilikuva todellisuudesta. Kuolemassa on kuitenkin paljon myös yhteistä ja jaettua. Eri kirjoittajien eutanasiapuheesta löytyy niin paljon samanlaisuutta, että 


\section{KIPU JA KUOLEMA}

on mahdollista puhua esimerkiksi kristillisestä eutanasiapubeesta (3), jossa tehdään selkeä ero inhimillisten toimijoiden ja Jumalan välille. Toisaalta kaikki eutanasiapuhe ei ole eksplisiittisesti kristinuskoon viittaavaa eikä kristillisessä puheessa aina esimerkiksi torjuta eutanasiaa. Eutanasian hyväksyvä puhe nousee tavallisimmin sellaisista näkemyksistä, joissa vedotaan kuolevan ihmisen kärsimysten lopettamiseen. Eutanasiapuhe voikin sisältää perinteisiä uskonnollisia elementtejä mutta myös sellaisia uskomuksia, joissa ei puhuta jumalista, henkiolennoista tai muista yleensä uskonnon piiriin prototyyppisesti liittämistämme toimijoista (ks. Saler 2000).

Peter Bergerin ja Thomas Luckmannin (1994) sosiaalista konstruktionismia edustavan, jo klassikoksi muodostuneen teorian mukaan tiedolla on perustansa sosiaalisessa todellisuudessa. Myös Mary Douglasin ja Émile Durkheimin ajatusten nähdään perustuvan sosiaalisesti rakentuville todellisuuskäsityksille (Douglas 1975; Durkheim 1980). Eutanasiapuhetta voidaan tarkastella tällaisena sosiaalisesta maailmasta nousevana ja saman kulttuurin jäsenten yhteistä tietämystä ilmentävänä. Artikkelissani huomio kiinnittyy ensisijassa toistuviin ja samansuuntaisïn metaforiin eli kielikuviin, joiden avulla rakennetaan sairautta, kärsimystä ja kuolemista koskevia käsityksiä. Metaforia käytetään merkitysten luomisessa ja tiedollisten perustelujen antamisessa puheena oleville asioille (Anttonen 1996, 31; Lakoff \& Johnson 1981, 7).

Kirjeaineistoa lukiessani kiinnitän huomioni siihen, torjutaanko vai hyväksytäänkö eutanasia ja kuinka ehdotonta suhtautuminen siihen on. Olen kiinnostunut myös siitä, millaisten metaforien avulla eutanasiaa määritellään ja millaisia perusteluja erilaisille kannanotoille annetaan. Kirjeistä nousevan puheen ja siihen liittyvän metaforisen kielen voi katsoa kertovan jotakin siitä, mitä pidetään kuoleman hetkessä tärkeänä ja mitkä asiat ovat moraalisilla arvoilla ladattuja. Esimerkiksi kristillisessä eutanasiapuheessa "Jumalan kuva" -metafora viittaa ihmisen erityiseen arvoon ja symboloi jotain kristillisessä yhteisössä tärkeänä pidettyä. Eutanasian torjuvassa kristillisessä puheessa kuoleman "keinotekoinen jouduttaminen" uhmaa kristillisen yhteisön arvoja ja luonnollisena pidettyä järjestystä. Tästä syystä eutanasiapuhe on sosiaalista puhetta, jossa rakennetaan ja uusinnetaan yhteistä todellisuutta. Pubuttelu onkin keskeinen ihmisyyttä ja sosiaalisia suhteita ylläpitävä käytäntö: kun kohdistamme sanamme johonkin ihmiseen, konstruoimme hänestä jäsenen maailmaan, johon itsekin kuulumme (Peräkylä 1990, 31).

Meillä ei ole valtaa päättää omasta, eikä toisen ihmisen elämän lopettamisesta. Se valta on ykesin Isällä Jumalalla. [..] Jumala loi ibmisen omaksi kuvakseen, Jumalan kuvaksi hän hänet loi, mieheksi ja naiseksi hän loi heidät. [..] Kun perustelee mielipidettään elämää ja kuolema koskevissa kysymyksissä nïn mielellään tukeutuu Jumalan sanan meille antamiin vastauksiin. (KE 25.)

On muistettava, että ibminen on luotu Jumalan kuvaksi (1. Moos. 1:27). Parhaimmillaankin tämä kuva on synnin ja elämän katoavaisunden vuoksi turmeltunut. Tämän vuoksi kuoleva vanhuskin on Jumalan silmissä arvokas. (KE 14.) 


\title{
LEILA JyLHÄNKANGAS
}

\begin{abstract}
En kannata eutanasiaa missään tapauksessa. Ihmisen pitää antaa elää kaikeki vuodet ja päivät luonnolliseen kuolemaan saakeka. Nïn on Jumala tarkoittanut luodessaan tämän maailman. Sairaanakin saapi ibmiset elää. Se on Jumalan armoa. (KE 23.)
\end{abstract}

Ihmisyyttä ylläpitävä puhuttelu nousee esiin myös eutanasiapuheesta: eutanasian oikeutusta tai sen torjumista perustellaan esimerkiksi sosiaalisilla syillä, lääkäreiden etiikan ongelmana sekä kuolevan ja hänen omaistensa kärsimysten kautta. Ajattelen eutanasiasta kirjoittamisen myös omalla tavallaan vertautuvan uskonnollisesta kokemuksesta kertomiseen, jossa "uskova rajaa omaa identiteettiään yhteisönsä jäsenenä, suhteessaan yliluonnolliseen sekä uskovien yhteisön ulkopuolisuuteen", vaikka lähestymistapani eutanasiapuheeseen ei edustakaan narratiivista näkökulmaa (ks. Hovi 2004, 380-383). Omaa uskonnollista identiteettiä ja uskovien yhteisön jäsenyyttä rajattaessa voi tiivistyä huoli esimerkiksi oman yhteisön mahdollisesta epäyhtenäisyydestä:

Olen eutanasian vastustaja. [..] On birvittävää kun lääkäristä tehdään murhaaja, ihan laillisesti. [..] Raamatussa tappaminen kielletään. [..] Tulee kysyneeksi olemmeko me kristittyjä vai vain nimi sellaisia, suurin osa kansastamme kuulun omaan luterilaiseen kirk.koomme mutta seuraammeko Jeesusta? Jumala meitä armabtakoon. (KE 24.)

Tarkastelemani eutanasiapuhe kattaa joukon erilaisia uskomuksia, joiden vaihtelevuutta ja moninaisuutta ei voi jättää huomiotta. Ilmiöt voivat jäsentyä samankin kulttuurin sisällä eri tavoin, mikä on otettava ainakin mahdollisuutena huomioon jo tutkimuksen lähtökohdissa. Tässäkin aineistossa jo erilaiset eutanasiamääritelmät osoittavat kulttuurinsisäisen vaibtelevunden merkityksen. Tähän liittyen on kiinnostavaa, kuinka esimerkiksi suomen kielen sanan "mies" merkitys jäsentyy toisinaan vastakohtana "naisen" käsitteelle, toisinaan taas vastakohtana "pojan" käsitteelle. Näin ei siten ole mitään syytä olettaa, että "miehen" käsite muissa kulttuureissa toimisi samalla tavalla. (Ketola 1997, 229; vrt. Silverman 2001, 142.) Toisaalta kulttuuristen kategorioiden olemassaolon voi katsoa perustuvan jaettuihin sosiaalisiin merkitysjärjestelmiin (Ketola 1997, 234-235). Tällaisia sosiaalisia merkitysjärjestelmiä onkin mahdollista jäljittää eutanasiapuheesta etsimällä siitä samankaltaisuuksia (vrt. Eskola \& Suoranta 2000,181). Tyypittelen tällaiset samankaltaisuudet eutanasiaa koskeviksi puhetavoiksi. Esimerkiksi kristillisessä käsitejärjestelmässä ihmisen kategorian erityislaatuisuutta ilmentävä attribuutti on "Jumalan kuva". Ihmiselämää pidetään pyhänä tämän attribuutin ja sitä suojelevan kristillisen moraalikoodin "älä tapa" perusteella, mistä johtuen eutanasia nähdään ei-hyväksyttävänä kuolemisen tapana.

Erilaiset eutanasianäkemykset myös lähenevät toisiaan niin paljon, että niiden järjestäminen nimettyjen tyyppien (kuten "hyväksyvä" tai "torjuva" eutanasiapuhe) alle on mahdollista ja taloudellistakin. Tavallaan kysymys on myös tiivistämisestä, joka parhaimmillaan kasvattaa aineiston informaatioarvoa luodessaan 


\section{KIPU JA KUOLEMA}

hajanaisesta aineistosta selkeää ja mielekästä (Eskola \& Suoranta 2000,137). Tällaisessa laadullisessa lähestymistavassa ei kuitenkaan olla kiinnostuneita siitä, ovatko aineistossa esiintyvät käsitykset itsessään "totta" siinä mielessä, että niiden perusteella voitaisiin tehdä johtopäätöksiä myös aineiston ulkopuolisesta maailmasta. Tavoitteena on pikemminkin ymmärtää, millaisia kategorioita aineistossa esiintyy ja miten niitä aineistossa käytetään. (Silverman 2003, 348-349; Silverman 2001, 124, 128.)

Oletukseni on, että eutanasiapuheen kielikuvien sisältöä määrittävät ihmisruumiiseen kytkeytyvät kulttuuriset ja yhteisölliset kategoriaerottelut. Tässä mielessä jo aineiston lukutapani sisältää kategoriateoreettisia orientaatioita, joiden taustalla on oletus kulttuuristen kategorioiden perustavanlaatuisesta asemasta eutanasiapuheessa. Tuen näin ajatusta siitä, ettei tutkimus voi koskaan olla täydellisesti teoriavapaata, toisin sanoen ilman minkäänlaista taustateoriaa tapahtuvaa (ks. Silverman 2001, 70). Tarkastelen eutanasiapuhetta lukemalla siitä hyvinä ja oikeanlaisina pidettyjä elämän ja kuoleman välisen rajanylityksen keinoja. Rajanylitystä koskevien merkityksillä ladattujen ilmaisujen näen toimivan eutanasiaa ja siihen liittyen sairautta ja kuoleman edessä olevaa inhimillistä toimijaa koskevien kulttuuristen kategorioiden osoittajina.

\section{KULTTUURISET KATEGORIAT EUTANASIAPUHEESSA}

Ihmisruumiiseen kytkeytyvät kulttuuriset ja yhteisölliset kategoriaerottelut märittävät eutanasiapuheen kielikuvien sisältöä. Kategorioiminen on perustavanlaatuinen toiminto inhimillisessä ajattelussa, havaitsemisessa ja toiminnassa. Näemme erilaiset konkreettiset ja abstraktit asiat, esimerkiksi sairauden tai sosiaaliset suhteet, tietynlaisina. (Lakoff 1990, 5-6). Ihminen erottelee ja rajaa asioita kategorioiksi ja on myös tietoinen kategorioiden sisällöistä (Pyysiäinen 1997, 182183). Eutanasiakannanottoja ajatellen kiinnostava näkemys koskee kategorioista tietoiseksi tulemista erityisesti sellaisissa tilanteissa, jotka koetaan ongelmallisina (Lakoff 1990). Yhdentekevinä pidettyjä asioita koskeva kategorioiminen on automaattista ja usein tiedostamatontakin, mutta esimerkiksi kuoleman kaltaista perustavanlaatuista kulttuurista kategoriaa koskevat luokitukset vaativat ihmiseltä tietoisempaa pohdintaa. Kuolemaa edeltäviä koettelemuksia voidaan kategorioida useilla eri tavoilla, ja niitä koskevat erilaiset mielikuvat ovat läsnä kärsivään ihmisruumiiseen liittyvissä pohdinnoissa. Tällaiset kärsimysrepresentaatiot eivät kuitenkaan ole eutanasiapuheessa kaikkialla samanlaisia, vaan ne saavat sisältönsä sen mukaan, millaisten kannanottojen yhteydessä niitä muodostetaan.

Uskonnot eivät ole vain luokittelun kohteita vaan myös kulttuuristen luokitusjärjestelmien aktiivisia tuottajia. Yksi perinteisistä uskonnollista kategorioinneista on jako pyhään ja profaanïn (esim. Durkheim 1980), samoin jako pubtaaseen ja epäpubtaaseen (Douglas 1989; myös Anttonen 1996). Mary Douglasin (1989) ajattelussa keskeistä ovat ihmisruumiiseen liitetyt puhtautta ja epäpuhtautta koskevat 


\section{LEILA JYLHÄNKANGAS}

kulttuuriset merkityksenannot sekä näihin liittyen ihmisruumiin ja yhteisön symbolinen rinnastussuhde toisiinsa (Anttonen 1996; ks. myös Anttonen \& Viljanen 2000). Tämä on kenties hänen teoriansa metodisesti kiintoisin huomio. Douglasia seuraillen näen, että ihmisruumis toimii sekä yksilöllisen että yhteisöllisen käyttäytymisen orientaation keskuksena ja artikkelini taustalla keskeisenä on huomio uskonnon ruumisperustaisuudesta (Douglas 1989; Anttonen 1996; ks. myös Ahonen 2004 ja Jylhänkangas 2001, 2004). Uskonto on osa ihmisen fyysistä olemassaoloa ja myös ajattelua, jossa kulttuurisia merkityksenantoja rakennetaan. Eutanasiapuhekin on ihmisruumiiseen kytkeytyvää ja sen merkitsemää. Ihmisruumiin kärsimyksistä puhutaan esimerkiksi seuraavilla tavoilla:

Nykyään ihmiset elävätpitkään ja sairastavat kaikenlaisia sairauksia. Kun tulee kipua ja kärsimystä tulee mieleen auttaa ibmistä pois kärsimyksistään. (KE 128.)

Keubkosyövässä on loppuvaiheessa kovat kivut. On paljon kärsimystä, jota ei armahda kuin kuolema. (KE 65.)

Terveyteen ja sairauteen liitettyjen rajanvetojen lisäksi elämän ja kuoleman välinen ero on yksi merkittävimmistä kulttuurisista luokitteluista. Käytän ilmaisua kulttuurikobtainen, koska mielestäni kulttuuri-ilmiöiden tarkastelussa ei tulisi rajoittua esimerkiksi tutkimaan ainoastaan universaalia kognitiivista eli sitä, mitä ihmisen pään sisältä biologisesti löytyy. Siihen rajoittumalla emme pääse käsiksi nimenomaan tietylle kulttuurille ominaisiin ajattelun sisältöihin. Kuolemaa tutkineet antropologit ja uskontotieteilijät ovatkin omilla tavoillaan kunnostautuneet juuri kuoleman kontekstispesifien yhteisöllisten ja kulttuurikohtaisten ulottuvuuksien huomioimisessa tutkimuksissaan (ks. esim. Metcalf \& Huntington 1999; Pentikäinen 1968; Pentikäinen 1990; Utriainen 1999; Fingerroos 2004). Artikkelini taustalla on kuitenkin myös kognitiivisuusoletus: ihmisellä on kyky rakentaa, muistaa ja ilmaista mentaalisia representaatioitaan, jotka ovat kulttuurisia ja ainakin jossakin määrin jaettuja (Sperber 1987, 30; ks. myös Sperber 1996). Eutanasiapuheesta nousevien jaettujen representaatioiden sisältöjen tarkastelu avaa kiinnostavia näkökulmia paitsi kuolemaa koskevan tiedon problematiikkaan myös siihen, miksi kuolemasta halutaan puhua ja sitä koskevia uskomuksia levittää (Jylhänkangas 2004). (4)

\section{KIPU JA KÄRSIMYS TOISIINSA KIETOUTUVINA}

Kipua voidaan määritellä ja käsitteellistää monella tavalla. Yhtäältä sitä voidaan kuvata fyysisiä tuntemuksia sisältävänä fysiologisena tilana ja kokemuksena, joka vaihtelee lyhytkestoisesta tuntemuksesta pitempiaikaiseen krooniseen kipuun. Toisaalta kipuun liittyy mentaalisia ja kulttuurisia tekijöitä, jotka voivat paikantua esimerkiksi kuolemiseen liittyviin tilanteisiin. Kivun tavoin myös kärsimys liittyy kuole- 


\section{KIPU JA KUOLEMA}

miseen. Ariel Glucklich kirjoittaa, että käsitteellisellä tasolla kipu ja kärsimys olisi kuitenkin hyvä erottaa toisistaan. Kärsimystä nimittäin voidaan pitää emotionaalisena reaktiona, johon ei välttämättä liity kipua. Esimerkiksi lapsen menettäminen aiheuttaa kärsimystä ja surua muttei välttämättä fyysistä kipua. (Glucklich 2001, 1112.) Fyysistä kipua puolestaan voidaan tarkastella puhtaan lääketieteellisenä ongelmana, jota lievitetään kipulääkityksen avulla. Tällöin ei kuitenkaan välttämättä huomioida, että kivun kokemisen ja ilmaisemisen taustalla on myös psyykkisiä, sosiaalisia ja kulttuurisia tekijöitä (ks. Estlander 2003; Greenhalgh 2001; Morris 1993; Honkasalo 1999; Havas 1994). (5)

Eutanasiakirjeissä kipu on osa kuolemista koskevaa puhetta, jossa pohditaan ihmisruumiin fyysisiin sairauksiin liittyviä ruumiillisia koettelemuksia. Toisinaan kipua käytetään myös synonyyminä kärsimykselle. Eutanasiapuheesta nousevat esille nimenomaan kuolemiseen ja kuolemaa edeltävään sairauteen liittyvät kipuja kärsimysrepresentaatiot. Sekä yksilö- että yhteisötasolla kivusta kertominen (puhumalla, kirjoittamalla tai arkipäivän elämässä toimimalla) onkin yksi tapa pukea kärsimystä sanoiksi ja tehdä se tiettäväksi myös toisille kulttuurin jäsenille. Tällainen kertominen voi olla myös poliittista. Omasta kertomuksesta saatetaan haluta luoda vaihtoehtoinen versio, joka ei rajoitu lääketieteelliseen määritelmään "potilas ja diagnoosi”. (Greenhalgh 2001, 232-233.)

Millaisista kivuista ja kärsimyksistä eutanasiakirjeissä sitten konkreettisesti puhutaan? Hyvin usein kirjoittajat nostavat esille oman tai läheisensä kärsimyskokemuksen. He myös kirjoittavat elämän loppuvaiheen koettelemuksista, kivusta ja tuskasta: siitä, miten näitä kokeva ihminen "kykeni tuntemaan kipua ja kärsimystä ja nöyryytystä":

\section{Hän ei pystynyt kävelemään, hän ei tuntenut ketään läheisistään, ajan ja paikan taju oli kadonnut, ulostaminen hoitui lähinnä manuaalisesti suolet tybjentäen tai vaippoibin virtsaamalla, jne. En voi sanoa, että hän olisi enää ollut ns. täysissä henkisissä voimissaan, mutta kipua ja kärsimystä ja nöyryytystä hän kykeni tuntemaan. (KE 36.)}

Eutanasiapuheessa kärsimystä puetaan sanoiksi pohtimalla kuoleman hetkeä edeltäviä kipuja, jolloin kipu ja kärsimys kietoutuvat tiiviisti toisiinsa. Näin eri sairauksissa usein käytännössäkin tapahtuu. Esimerkiksi sepelvaltimotaudissa ja sydäninfarktissa sairastunut ruumis aiheuttaa kärsimystä, joka saattaa rajoittaa liikkumista ja aiheuttaa kipua. Ruumiillisen sairauden laukaisema kärsimys myös koetaan ainutkertaisesti, ja etnografinen tarkastelu auttaa ymmärtämään, kuinka kärsimys rakentuu erilaisissa tilanteissa. (Soivio 2004, 167-168, 172; ks. myös Utriainen \& Honkasalo 2004; Greenhalgh 2001.) Kärsimys on kenties yhtä laaja käsite kuin uskontokin. Tilanne on samantapainen kuin uskonto-ilmiön kohdalla. Mitään tiettyjä uskonnoksi tekeviä ehtoja on vaikeaa löydä tiukasti lukkoon, joskin uskonnolle on hyvin perustellusti osoitettu olevan ominaisia sellaiset tuntomerkit kuten intuition vastaisuus, erottamisen ja rajaamisen logiikalle perustuva kulttuurisidonnainen pyhittäminen sekä usko yli-inhimillisiin toimijoihin (Boyer 1994; Pyysiäinen 2001; Anttonen 1996 


\section{LEILA JYLHÄNKANGAS}

ja 2002; Lawson \& McCauley 1990). Kysymys on myös kontekstisidonnaisista asioista, joiden suhteen tehtävät määritelmät rakentuvat kulloinkin kysymyksessä olevan aineiston ja tutkimuksen rajoissa.

\section{EUTANASIAN TORJUMINEN}

\section{JA VÄLTTÄMÄTTÖMÄN KÄRSIMYKSEN LIEVITTÄMINEN}

Eutanasian torjuvassa puheessa kuolemiseen katsotaan kuuluvan tietty määrä kärsimystä, jota voidaan vain lievittää. Seuraavassa kirjoituksessa korostetaan, että elämän lähestyessä loppuaan tarvitaan taitoa hoivata kuolevaa tämän "viimeisissä tuskissa". Ensimmäisessä tekstissä elämän ja kuoleman välisen rajan ylitys on Jumalan hallinnassa. Jälkimmäisessä kirjoituksessa korostetaan ihmiselämän pyhyyttä ja painotetaan, ettei ihmisellä ole oikeutta lyhentää elämää. Eutanasiasta puhutaan "Jumalaa vastaan" kohdistettuna "kapinana". Jumala on elämän ja kuoleman välisen rajan ylittämisen keskeistoimija, ihmisen tehtävänä puolestaan on "huolehtia heikoista”. Näissä kirjoituksissa maailma saa muotonsa suhteessa jumala-käsitteeseen, jonka varaan koko elämä rakennetaan (vrt. Pyysiäinen 1997, 232).

\section{Lähimmäisen auttamisessa, erityisesti hänen sairastaessaan ja valmistautuessaan poistumaan elämästään, tarvitaan taitoa hoivata bäntä viimeisissä tuskissa. Me emme ole saaneet tuskatonta elämää. Jumala ei ole säästänyt omaa poikaansa eikë hän säästä meitäkään, mutta Jumala seuraa meitä loppuun asti lupauksensa mukaan ja bän tietää hetken, jolloin hän ottaa meidät pois täältä. (KE 6.)}

Kenelläkään ihmisellä - ei edes lääkärillä- ole oikentta lyhentää elämää, sillä se on pybää. [..] Jokaisen vanbuksen on saatava mennä sairaalaan turvallisella mielellä rï̈pumatta ikävnosien määrästä. Velvollisuutemme on buolebtia heikoista. [..] Kapina Jumalaa vastaan - pyytämällä eutanasiaa - ei byödytä ihmistä $y$ htään, sillä jokaisen on kuitenkin kerran itse vastattava Jumalalle elämästään. (KE 9.)

Kristillisessä eutanasiapuheessa pohditaan usein myös saattohoidon (6) mahdollisuutta. Yksi kristillisen kulttuurin ytimessä oleva kuolemakuva käsittääkin ajatuksen yksilön, ristiinnaulitun, kärsimystäyteisestä kuolinkamppailusta, toinen taas läheisen toisen ihmisen kärsimyksestä (Utriainen 1999, 15; Utriainen 2004, 246, vrt. myös KE 6 edellä). Eutanasian avulla toimeenpantu kuolema koetaan keinotekoisena. Kristilliseen saattohoitoideologiaan perustuvat "kivun hoitoon keskittyvät saattokodit" sen sijaan nähdään "esimerkillisinä kuolevan ihmisen hoitopaikkoina", joissa ihmisen "annetaan kuolla arvokkaasti". 


\section{KIPU JA KUOLEMA}

Oma mielipiteeni eutanasiasta on se, että en kannata kuoleman kiirehtimistä keinotekoisesti. [..] Saattokodit ovat esimerkillisiä kuolevan ibmisen hoitopaikekoja. Niissähän keskitytään kivun hoitoon ja annetaan ibmisen kuolla arvok.kaasti. [..] En kannata eutanasiaa, vaan ibmisen luonnollista kuolemaa. (KE 11.)

Kipua ja kärsimystä koskevat representaatiot kietoutuvat eutanasiapuheessa yhteen, vaikka kivun nähdäänkin usein paikantuvan konkreettisiin ruumiillisiin tuntemuksiin. Vakava sairaus aiheuttaa voimakkaita kipuja ja emotionaalista kärsimystä niin sairastuneelle kuin hänen läheisilleenkin. Esimerkiksi syöpään liittyy fyysisiä kipuja, joita ei voida täysin erottaa sairastuneen ja hänen omaistensa emotionaalisista kärsimyksistä. Kärsimys rakentuu kontekstisidonnaisesti, toisin sanoen kärsimystä ei ole olemassa ilman sitä ajattelevaa ja kokevaa yksilöä ja hänen yhteisöään. Kristillisessä eutanasiapuheessa Jumalan nähdään tietävän, "milloin on ihmisen aika lähteä tästä maailmasta”, eikä eutanasiaa nähdä hyväksyttävänä keinona "auttaa ihmistä pois kärsimyksistään".

Jumala tietää milloin on ihmisen aika lähteä tästä maailmasta. Kenenkään ei pidä ruveta leikekimään Jumalaa toisen elämän päättämisestä. [..] Ymmärrän kyllä että tällaiseen avustettunn kuolemaan on houkutuksia. Nykyään ibmiset elävät pitkeään ja sairastavat kaikenlaisia sairanksia. Kun tulee kipua ja kärsimystä tulee mieleen auttaa ihmistä pois kärsimyksistään. Mutta eutanasia ei ole oikea keino. (KE 128.)

Jumala on määrännyt jokaiselle syntymähetken ja kuolinajan, jo kohdussa ollessa. Missään vaiheessa ei lääkärillä ole oikeutta päättää ibmisen elämää antamalla kuolonpiikekiä. (KE 18.)

Eutanasian torjuvassa kristillisessä puheessa kuolemasta päättäminen kuuluu Jumalalle. Rinnasteisia näkemyksiä nousee esille myös suomalaisesta aborttipuheesta. Salome Tuomaala esimerkiksi kirjoittaa, kuinka kristillisessä puheessa abortti liitetään syntiin (Tuomaala 2004, 139). Eutanasiapuheen kristillis-torjuvissa näkemyksissä katsotaan, ettei ihmisen tule astua kuoleman käsittelyssä Jumalan paikalle lopettamalla kärsimyksiä kuoleman ajankohtaan puuttumalla. Kärsimystä kuitenkin katsotaan voitavan käsitellä käytännöllisesti toimien (ks. Utriainen 2004, 245) esimerkiksi kipua lievittävän lääkityksen ja saattohoidon avulla.

\section{TOIMIVAN JA TOIMIMATTOMAN IHMISRUUMIIN VÄLINEN RAJANKÄYNTI HYVÄKSYVÄSSÄ EUTANASIAPUHEESSA}

Ruumiillisuus on olennainen tekijä sekä syntymän ja kuoleman kaltaisten eksistentiaalisten kysymysten kohdalla että inhimillisen vuorovaikutuksen kannalta. "Ruu-

miilliset ihmiset ovat suhteessa toisiinsa näkyvän ruumiin välityksellä, ruumiin joka 


\section{LEILA JYLHÄNKANGAS}

näkee ja voidaan nähdä” (Tedre 1996, 2). Aivan samoin ruumiillisuus on olennaista myös uskonnollisen toiminnan kannalta, vaikka sen merkitystä joskus vähätellään (esim. Ahonen 2004). Eutanasiapuheessa yksi ruumiillisuuteen kytkeytyvä ja sellaisena ihmisen paikkaa elämän ja kuoleman välisellä rajalla määrittävä keskeinen käsitteellinen alue liittyy toimivan ja toimimattoman ihmisruumiin väliseen rajankäyntiin, joka synnyttää eutanasian hyväksyvää puhetta:

Olen ehdottomasti eutanasian puolestapuhuja. Haluaisin itselleni sellaisen kun olen jo avuton ja letkujen varassa. [..] On aivan turbaa hoitaa aivokuolleita ja tiedottomia eläviä ruumiita. Varat voisi käyttää terveempien byväksi. (KE 89.)

Toimivan ja toimimattoman ihmisruumiin välistä rajankäyntiä ilmentävän puheen perusteella tulkitsen, että elintoimintojen ylläpitämisessä toisten ihmisten välttämätöntä ympärivuorokautista hoivaa tarvitsevat ihmisruumiit mielletään eutanasiapuheessa välttämättömyylesien ruumïlesi. Silva Tedre pohtii vanhusten hoivasta kirjoittaessaan, kuinka hoivatilanteessa on läsnä kaksi ihmistä: apua välttämättömyyksissään tarvitseva ihminen ja apua antava ihminen. Hän kuvaa, kuinka hoivatyö on toisen ihmisen ruumiiseen liittyvää työtä. Tedre viittaa myös Mary Douglasin (1966) puhtautta ja epäpuhtautta koskevaan teoriaan ja näkee hoivatyön olevan "kiinteästi yhteydessä likaiseen, erityisesti kulttuurissamme intiimiksi tai tabuksi määriteltyyn likaiseen". (Tedre 1996, 1-4.)

Eutanasiapuheessa ihmisruumiit ovat elämän ja kuoleman välisellä rajalla, jonka arvokasta ylittämistä juuri välttämättömyyksien ruumiina oleminen uhkaa. Tällaisessa hajoamisen tilassa (vrt. Douglas 1989, 173) olevat raihnaiset ihmisruumiit tai "aivokuolleet ja tiedottomat elävät ruumiit" (KE 89) kamppailevat ihmisarvoisen ja ei-ihmisarvoisen kuoleman välisellä rajalla. (7) Toimimatonta ihmisruumista kuvataan eutanasiapuheessa esimerkiksi ilmaisulla "vihannes", johon ei-toivottuun kuolemaan liitetyt merkitykset kytketään ja jonka kautta myös eutanasian hyväksyviä kannanottoja usein perustellaan. Seuraavassa "vihanneksena" elämisen nähdään estävän "omin avuin liikkumisen", "tekemisen" ja "itsestä huolehtimisen", minkä katsotaan tekevän elämisestä ei-ihmisarvoista:

Itse olen ajatellut sen niin [..], etten esim. haluaisi elää ns. "vihanneksena", muiden elintoimintojen ollessa ok tai laitteiden varassa. [..] Myöskin jos ymmärtäisin asiat, mutten pystyisi koskaan omin avnin liikkeumaan tai tekemään mitään ja buolebtimaan itsestäni, haluaisin varmaan pois sellaisesta elämisestä, eihän se olisi ihmisarvoista elämistä ja sïnäkin tapanksessa olisi läheistensä vaivana ja suruna. (KE 38.)

Ihmisyytemme ei olisi mahdollinen ilman biologista perustaansa, ja sekä sen että yhteisön jäsenyyden rakentumisessa sosiaalinen ja biologinen on sidottu toisiinsa. Tästä huolimatta biologista ja sosiaalista voidaan ylläpitää niitä eri aikoina eri tavoin painottaen tai priorisoiden. Antropologisissa tutkimuksissa on yhtäältä kuvattu, kuinka ihmisyyttä ylläpitävät käytännöt voivat erilaisten rituaalien kautta jat- 


\section{KIPU JA KUOLEMA}

kua kauas biologisen kuoleman jälkeen, toisaalta tuollaiset käytännöt voivat sairaalassa loppua jo ennen varsinaisen biologisen elämän päättymistä. (Ks. Peräkylä 1990, 32-33.) Eutanasiapuhetta ajatellen näen kiinnostavana huomion siitä, kuinka ruumiin raihnaisuus ja kyvyttömyys voidaan yhdistää myös mielen kyyyttömyyteen. Tällöin kyvyttömyyden itsen kontrolliin jollakin alueella katsotaan aiheuttavan kyvyttömyyttä kontrolloida käyttäytymistä toisillakin alueilla. (Tedre 1996, 2-7.)

Edellä (KE 38) välttämättömyyksien ruumiina oleminen oikeastaan vangitsee ihmisen. Hän on liikuntakyvytön eikä pysty huolehtimaan itsestään, mikä estää täysipainoisen ja ihmisarvoisen elämisen. Tällaisessa tilassa oleva ihminen voi "ymmärtää asioita" mutta ei kykene tekemään mitään muuta "omin avuin". Välttämättömyyksien ruumiina oleminen on myös osallistumisen ja ulkopuolisuuden välimaastossa olemista. Aivokuolleen potilaan tila on siinä mielessä erilainen, että sellaisena pidetty potilas määritellään vääjäämättömämmin täysin ulkopuoliseksi suhteessa yhteisöön ja sosiaaliseen maailmaan (ks. Peräkylä 1990, 29-30). Seuraavissa esimerkeissä toimivan ja sosiaaliseen maailmaan osallistuvan ihmisruumiin vastakohtana pidetään "letkuissa ja aivokuolleena" olevaa ihmistä, joka ei kykene edes hengittämään. Uhkaksi koettu ehdotus "piuhojen pois ottamisesta" ilmentää, kuinka välttämättömyyksien ruumis suistuu sosiaalisen maailman ulkopuolelle. Elävän ruumiin syöttäminen "myrkkylääkkeillä" ja pitäminen "koneilla letkuissa" on pahimmillaan "raakaa ja rääkkäystä":

Ibminen on letkuissa ja aivokuolleena. Jossain vaiheessa kysytään omaisilta, että otetaanko piuhat pois kun ei itse kykene esim. hengittämään. Eikös tämä ole eutanasiaa. Se vain tapabtuu eri nimellä. Kyllä minun mielestäni. Meillä kaikilla on oikeus arvokekaaseen kuolemaan. Sen tähden tääläpitäisi byväksyä eutanasia sillä sanalla eikë millään muulla verukkeeella. (KE 81.)

Vaikeka ihminen olisi jo elävä ruumis pidetään bäntä koneilla letkuissa, syötetään myrkekylääkkeeitä ja annetaan pistoksia, että ei vain benki läbtisi. Se on raakaa ja rääkeäystä, pahemman laatuista. (KE 109.)

Toimivan ja toimimattoman ihmisruumiin välistä rajankäyntiä käsittelevässä eutanasiapuheessa ollaan usein huolestuneita juuri elämän pitkittämisestä sellaisessa tilanteessa, jossa ihminen mielletään jo "eläväksi ruumiiksi” (KE 109). Kaikissa eutanasian hyväksyvää puhetta edustavissa kirjeissä ei kuitenkaan käytetä toimimattomasta ihmisruumiista sellaisia metaforia kuin "vihannes" tai "elävä ruumis". Seuraavassa esimerkiksi puhutaan "kovista fyysisistä kärsimyksistä" ja elämästä, joka on "pelkkiä tuskia". Eutanasialle ja "tuskien lopettamiselle" annetaan oikeus "etenkin silloin, kun fyysiset kärsimykset ovat kovat". 


\title{
LEILA JYLHÄNKANGAS
}

\begin{abstract}
Mielestäni jokaisella ibmisellä pitäisi olla mahdollisuus päättää omasta elämästään ja kuolemastaan etenkin silloin, kun fyysiset kärsimykset ovat kovat. Jos ibminen kokee, että bänen elämänsä on pelk.kiä tuskia eikä bän voi niistä mitenkään parantua, tulisi lääkärillä olla oikeus auttaa bäntä lopettamaan tuskat, eli auttaa bäntä kuolemaan nopeasti ja kivuttomasti. Se ei ole tappamista. Se on pelastus. (KE 54.)
\end{abstract}

Ihmiselämään ei suhtauduta yhteisöissä pelkkänä fysiologisena entiteettinä, vaan sillä ajatellaan olevan erityinen arvo (Mitchell 1990, 34-35). Eutanasiapuheessa nostetaan esille ajatus ihmisarvoisesta elämisestä, jonka yhtenä keskeisenä edellytyksenä pidetään omien ruumiintoimintojen hallintaa ja riippumattomuutta toisten ihmisten hoivasta. Seuraavassa esimerkissä korostetaan elämän arvokkuutta, mutta painotetaan myös kuoleman arvokkuutta, jota "kuitenkin täytyisi myös ajatella":

Elämä on aina arvokas asia. Ei siinä kieltäminen. Kuitenkin täytyisi myös ajatella sitäkin puolta, että ehkä joskus kuolemakin on arvokas asia. Tai ehkë arvokkaampikin joskus kuin elämä. (KE 42.)

Ajatus kuolemasta nostaa esille erilaisia merkityksiä, jotka koskevat erilaisten ruumiillisten tilojen, terveyden ja sairauden sekä elämän ja kuoleman välisiä muutoksia. Rajojen ylittämisessä ajankohtaistuvat muutoksen tilat ja niiden käsittelyn tavat vaikuttavat myös siihen, millaista kuolemisen tapaa pidetään arvokkaana ja hyväksyttävänä. Seuraavassa katkelmassa "arvokas poistuminen tästä maailmasta" näyttäytyy tuskattomana kuolemana. Äärimmäinen kipu ja kärsimys antavat oikeutuksen eutanasialle, mikäli sairastava ihminen sitä itse toivoo:

Subtaudun siis erittäin myötämielisesti eutanasiaan silloin, kun ibminen itse sen saa päättää. [..] Jos olisi mabdollista, toivoisin itselleni jo edellä kuvatussa vaiheessa [liikuntakyyttömäksi ja muistamattomaksi halvaantuneena] keinoa, jolla arvokekaasti poistuisin tästä maailmasta ja välttyisin niiltä tuskilta, joita jo pelkkä tietoisuns omasta tilasta tässä vaiheessa tuottaa, pubumattakaan todellisista fyysisistä tuskista. (KE 34.)

Edellä eutanasian katsotaan mahdollistavan ihmisruumiin tuskien ja toimimattomuuden haltuunoton sekä arvokkaan kuoleman, "arvokkaan poistumisen tästä maailmasta". Jeff McMahan pohtii kivun rationaalisia ja moraalisia ulottuvuuksia ja näkee, että äärimmillään kipu voi jopa täydellisesti dominoida ihmisen tietoisuutta (McMahan 2002, 229). Edellinen katkelma eutanasiapuheesta ilmentää myös tällaisia kivun määreitä ja kertoo, kuinka "jo pelkkä tietoisuus" omasta tilasta "liikuntakyvyttömäksi ja muistamattomaksi halvaantuneena" aiheuttaa "tuskia".

Kuten muissakin kulttuurisissa merkityksenannon paikoissa myös suomalaisessa eutanasiapuheessa kuolemaa ja siihen liittyviä kipuja ja kärsimyksiä raken- 


\section{KIPU JA KUOLEMA}

netaan suhteessa kontekstiin. Siinä esimerkiksi sairaalakontekstin eri toimijoille - lääkäreille, potilaille ja omaisille - esitetään suosituksia siitä, kuinka heidän tulisi toimia mahdollisissa kärsimyksen ja kuoleman tilanteissa. Tällainen eri toimijoihin kohdistettu puhe on yksi osoitus siitä, kuinka ihmisten puheella ja muilla teoilla on erilaisissa arkisissa tilanteissa omat sosiaaliset mallinsa ja lainalaisuutensa, jotka nousevat yhteisöllisyydestä ja ovat julkisia (Peräkylä 1990).

\section{KeINUVA EUTANASIAPUHE}

Torjuvan ja hyväksyvän eutanasiapuheen välistä löytyy näkemyksiä, joissa ei selvästi oteta kantaa siihen, tulisiko eutanasia hyväksyä vai ei. Puheelle on ominaista pikemminkin arveleva pohdinta. Miten tällainen keinuva eutanasiapuhe lähestyy kipuja ja kärsimyksiä? Seuraavassa katkelmassa kärsimyksen katsotaan päättyvän kuolemaan, jota on vain jaksettava odottaa. Samalla kannetaan huolta omaisten selviämisestä näiden rakastamasta ihmisestä luopumisen hetkellä. Katkelma sisältää myös kiinnostavan kielellisen ilmauksen, jossa kuolema personifioidaan (vrt. Lakoff \& Johnson 1981, 33-34). Siinä kuolema tulee "ilman piikkiäkin":

Voisin sanoa ihan suoraankin, että byväkesyn sen [eutanasian] ajatuksena. Mutta eihän se kyllä niin y ksinkertaista taida sittenkään olla, on niin paljon ajatuksia, joita se sana herättää, erilaisia eri ibmisellä. [..] Tuleehan se kuolema ilman piikkiäkin, kun vain kärsii ja jaksaa. Ja sitten ne vihoviimeiset omaiset, jotka rakastavat tätä omaistaan, eivätkä kertakaikkiaan voi luopua bänestä. Mitenkä niistä selviää! (KE 125.)

Seuraavassa kirjeessä nostetaan esille eutanasiasta päättämisen vaikeus. Eutanasiaa selvemmin siinä otetaan kantaa dystanasiaan. Kirje sisältää toiveen, ettei elämää pitkitettäisi sellaisessa tilanteessa, jossa parantumistoiveita ei ole. Puheen keinuva luonne tulee esille näkemyksessä eutanasiasta vaikeana ja monia mielipiteitä herättävänä kysymyksenä:

Eutanasia on vaikea ja varmasti on monenlaisia mielipiteitä ja jokainen mielipide on arvokas. Lisäksi toisten ihmisten elämästä on vaikea päättää myös lääkäreiden varmasti. Itse kuitenkin toivoisin ettei elämääni pitkitettäisi, jos kerran ei parantumistoiveita ole. Olisi hirveää olla esim. sidoksissa johonkin koneeseen ja vuosikausia vain odottaa. Onko se ihmisarvoista elämää? Ja ymmärtääkö sitä itse?! Toivottavasti ei joudu kokemaan sitä. [..] lähiaikoina näin läheisen pitkëaikaisen sairauden vaikutukset. Olisi suonut että hän olisi päässyt helpommalla.

[..] Toivottavasti edes kipulääkkeet edes jotenkin vei munt kivut pois. [..] Missä nyt on Jumala joka pitäisi tuoda avun?? Onneksi nyt hän on päässyt tuskistaan. (KE 103.) 


\section{LEILA JYLHÄNKANGAS}

Edellisessä kirjoituksessa nousee esille myös kokemus läheisen ihmisen pitkäaikaissairauteen liittyvistä kivuista, joita lääkkeiden toivotaan helpottaneen. Läheisen sairastamista kuvataan kirjoituksen lopussa myös käsitteellä "tuskat", joista tämä nyt on "onneksi päässyt". Tätä ajatellen kiinnostavaa, kuinka nykyaikaa on katsottu luonnehtivan juuri erilaiset yritykset lievittää kärsimystä (Utriainen \& Honkasalo 2004, 29; Morse \& Johnson 1991, 337-338). Tällaisia kärsimyksen lievittämismerkityksiä ilmentävää puhetta nousee esille erityisesti eutanasian torjuvasta ja keinuvasta puheesta.

\section{EUTANASIAPUHE KULTTUURISTEN}

\section{KÄRSIMYSREPRESENTAATIOIDEN JA USKONNON ILMENTÄJÄNÄ}

Eutanasiapuheessa kuolemaa pohditaan monilla eri tasoilla ja kulloinkin puheena oleva kuolemistilanne vaikuttaa myös kärsimystä koskevien representaatioiden rakentumiseen. Tässä mielessä eutanasiaa koskevia kannanottoja voidaan oikeastaan tarkastella vain näytteinä tai välähdyksinä siitä, millaista suomalainen eutanasiapuhe voi olla. Ihmisen käsitys todellisuudesta ei myöskään ole vakioinen ja pysyvä, ja erilaiset suhtautumistavat liittyvät monenlaisiin tilanteisiin. (Peräkylä 1990, 11, 15.) Eutanasiapuheessa pohditaan inhimillistä kärsimystä, jonka katsotaan kytkeytyvän vakavaan sairauteen, kuolinprosessiin, psyykkiseen kärsimykseen ja ruumiilliseen kipuun. Ruumiillisen kivun katsotaan hallitsevan kuolemista, ja kontekstista riippuen tärkeänä pidetään yrityksiä hallita kipua joko sitä lievittävän lääkityksen tai eutanasian avulla.

Kuolema on monessa mielessä kontekstisidonnaisesti määrittyvä tila. Samansuuntaisia ja jaettuja representaatioita tarkastelemalla päästään käsiksi merkityksellisinä pidettyihin kategorioihin. Eutanasiapuheessa nostetaan esille mielikuvia kärsivästä ihmisestä, jonka kärsimyksiä määrittävät hänen itsensä ja hänen ympärillään olevien ihmisten siihen liittämät merkityksenannot. Hyvinä ja oikeanlaisina pidettyjen kuolemisen tapojen kontekstisidonnaisuuden lisäksi eutanasiapuhe ilmentää myös sitä, kuinka sairaus - yhtä lailla kuoleminen - on ennemmin perinpohjaisesti sosiaalinen tila kuin kapeasti määrittyvä organismin biokemiallinen toimintahäiriö (Turner 1995, 37; ks. myös Morse \& Johnson 1991; Fortes 1979). Kuolemaa edeltävään sairauteen liittyvät kivun kokemukset ja sen lievittämisen tavat rakentuvat kontekstisidonnaisen kärsimyksen ehdoilla. Yhdet katsovat äärimmäisten kipujen aiheuttaman kärsimyksen antavan oikeutuksen eutanasialle, toiset taas näkevät keskeisenä kipuja lievittävän lääkityksen antamisen kuolevalle.

Nostan lopuksi esille ajatuksen uskonnon ilmenemisestä tilanteissa, joissa ihmiset ovat vastatusten erilaisten pysyvyyden ja muutoksen välisten jännitteiden ja niistä aiheutuvien epävarmuuksien ja arvoristiriitojen kanssa. Tämän näkemyksen mukaan uskontoa ja uskontoja eivät luo mitkään erityiset asiat vaan kategoria-

erottelujen ja merkityksenantojärjestelmien erilaiset painotukset ja vaihtelut. Us- 


\section{KIPU JA KUOLEMA}

konto kulttuurisena ilmiönä astuu usein esiin tilanteissa, joissa kulttuurissa vaalittuja asioita ryhdytään määrittelemään uusilla tavoilla. (Anttonen 1997.) Puhe eutanasian hyväksymisestä tai torjumisesta nostaa esiin erilaisia arvoristiriitoja, joiden ratkaisemisessa merkityksellisillä kulttuurisilla kategorioilla on keskeinen tehtävä. $\mathrm{Ne}$ määrittelevät, kuinka elämän ja kuoleman välinen raja ylitetään oikein.

Kuolemaa koskevien kulttuuristen kategorioiden turvaaminen - niiden jatkumisesta ja säilymisestä huolehtiminen - motivoi eutanasiapuhetta (8). Se on osoitus siitä, kuinka kuolemaa määrittävät biologisten selitysten ohella - tai kenties vielä voimakkaammin - kulttuuriset ja uskonnolliset merkityksenannot. Kuolemaa ajateltaessa ja siitä puhuttaessa uusinnetaan kulttuurisen tietovarannon piirissä olevia uskomuksia, sääntöjä ja käsityksiä, jotka määrittävät inhimillisen toimijan rajoja ja mahdollisuuksia kuoleman edessä. Jo pelkkä ajatus kuoleman jouduttamisesta moraalisena ja inhimilliseen kärsimykseen kietoutuvana kysymyksenä muodostaa otollisen alustan tällaisia kulttuurissa arvossa pidettyjä asioita koskevien uskomusten esiintymiselle.

\section{VIITTEET}

1. Aineistoni koostuu 132 kirjeestä, joissa suomalaiset yksityishenkilöt pohtivat ja perustelevat suhtautumistaan eutanasiaan. Nämä kirjeet ovat osa tekeillä olevan uskontotieteen väitöstutkimukseni aineistoa. Viittaan kirjeaineistoon seuraavasti: $\mathrm{KE}$, kirjeen numero. Olen kerännyt aineiston uskontotieteen pro gradu -tutkielmaani (Jylhänkangas 2001) varten useissa suomalaisissa sanoma- ja aikakauslehdissä julkaistuin kirjoituspyynnöin "Kirjoita eutanasiasta". Kirjoituspyynnön sanamuodon ja eutanasian määrittelyn tein mahdollisimman selkeäksi, jotta kynnys kirjoittaa ei nousisi korkeaksi ja periaatteessa kuka tahansa voisi kirjoittaa. Kirjoituspyyntöjä oli kaksi (ks. liitteet), joista ensimmäisessä eutanasialle annettiin "fyysisellä tasolla" pidättäytyvä määritelmä, toisessa eutanasiaa ei määritelty lainkaan. Useimmiten kirjoittajat kuitenkin määrittelivät eutanasian käsitteen kummassakin tilanteessa itse. Kirjoituspyynnöissä ei mainittu, minkä oppiaineen pro gradu -tutkielmaa varten aineistoa on tarkoitus kerätä. Näen, että uskontotieteen ja samalla sen sisältämän uskonto-sanan mainitseminen kirjoituspyynnössä olisi voinut motivoida kirjoittajia pohtimaan eutanasiaa lähinnä uskonnon näkökulmasta ja vastaavasti nostaa kirjoittamiskynnystä sellaisten henkilöiden kohdalla, jotka eivät koe itseään erityisen uskonnollisiksi.

2. Käytännössä ja fyysisellä tasolla toteutettuna aktiivinen eutanasia tarkoittaa tavallisesti joko sitä, että lääkäri antaa potilaalleen suonensisäisesti ylisuuren annoksen morfiinia tai sen analogia, joka vaivuttaa potilaan uneen ja lamaa sitten hengityksen, tai lääkäri antaa potilaalle ensin unilääkettä ja sen jälkeen kaliumkloridia, joka lopettaa sydämen toiminnan. Passiivinen eutanasia merkitsee jostakin hengen mahdollisesti pelastavasta toimenpiteestä luopumista, jolloin potilas kuolee sairauteensa. (Louhiala 1995, 113-115; ks. myös Jeffrey 1993, 64-65, 72; Pahlman 2003, 305- 


\section{LEILA JYLHÄNKANGAS}

310.) Raja aktiivisen ja passiivisen eutanasian välillä on kuitenkin usein epäselvä, sillä myös passiivisen eutanasian voi ajatella omalla tavallaan olevan "aktiivista väliintuloa”, sillä siinä toimenpiteet kuoleman viivästyttämiseksi tietoisesti lopetetaan. Suomessa aktiivista eutanasiaa ei ole laillistettu. Rikosoikeudelliselta kannalta tuollainen teko täyttäisi todennäköisesti surmarikoksen tunnusmerkistön (ks. Pahlman 2003, 340).

3. Tarkoitan kristillisellä eutanasiapubeella niitä eutanasiakannanottoja, joissa viitataan selkeästi kristinuskon piiriin katsottaviin asioihin, kuten Jumalaan tai Raamattuun. Kristillisessä eutanasiapuheessa kuolemasta päättäminen nähdään Jumalan tehtävänä ja Raamattu käsitetään keskeiseksi auktoriteetiksi elämän ja kuoleman välisen rajan ylittämisen tapoja määriteltäessä. Tällainen yleisluontoinen näkökulma ei kuitenkaan paljasta, millaisesta kristillisyydestä tai kristinuskon muodosta yksityiskohtaisemmin on kysymys, eivätkä eutanasiapuhujat sitä yleensä itsekään tarkenna. Eutanasian kristillisin perustein torjuvaa puhetta olen nimittänyt kristillistorjuvaksi diskurssiksi, eutanasian kristillisin perustein hyväksyvää puhetta puolestaan kristillis-hyväksyväkesi diskurssiksi. Nimitysten "torjuva" tai "hyväksyvä" tarkoituksena ei ole arvottaa. Ne koskevat sitä, kuinka kirjoittajat eutanasiaan suhtautuvat: yleensä sen torjuen tai hyväksyen. (Jylhänkangas 2004, 328-334; 2001, 99-116, 123-124.) Vaikka kirjeaineistoni ei edusta tilastollista otosta, on huomattava, että kristillis-hyväksyvä ja keinuva diskurssi (ks. "Keinuva eutanasiapuhe" tässä artikkelissa) ovat aineistossani selvästi vähemmistössä. Keinuvan diskurssin piiriin katsottavia kirjeitä olen löytänyt aineistostani vain viisi ja kristillis-hyväksyviä kaksi. On kuitenkin huomattava, että keinuvan eutanasiapuheen piiriin kuuluvat näkemykset saattavat usein olla enemmän eutanasian hyväksyviä kuin sen torjuvia.

4. En puutu tässä artikkelissa siihen, onko ruumisteoreettinen näkökulma ristiriidassa kognitiivisen lähestymistavan kanssa. Tässä tyydyn vain toteamaan, että näen nämä kaksi pikemminkin toisiaan täydentävinä kuin toisensa poissulkevina näkökulmina.

5. Tämän artikkelin puitteissa ei ole mahdollista antaa kattavaa selitystä sille, millä kaikilla mahdollisilla tavoilla kipua voidaan määritellä ja kuvata. Kivun kokemista on tutkittu esimerkiksi lääketieteen antropologisista lähtökohdista käsin (ks. esim. Honkasalo 1999). Kivun kokemuksen erilaisista kulttuurintutkimuksellisista näkökulmista ks. myös Utriainen \& Honkasalo 2004, 41-45. Utriainen ja Honkasalo kirjoittavat, että kärsimystä on tutkittu empiirisesti ensisijaisesti antropologian, sosiologian, perinteentutkimuksen ja naistutkimuksen alueilla (ks. Utriainen \& Honkasalo 2004, 31).

6. Saattohoidon käsitteellä tarkoitetaan kuolevan potilaan hoitoa, johon kuuluu sekä oireiden lievittämistä että potilaan tukemista. Siihen sisältyy myös eksistentiaalinen ulottuvuus käsitteen kuvatessa "kuolevan saattelemista matkalle, kotiin tai portaille, jolta ei ole paluuta". (Vainio 1993, 23.)

7. Eutanasian hyväksyvässä puheessa representaatio radikaalisti heikentyneestä, fyysisen toimintakykynsä menettäneestä ihmisruumiista viittaa sairauden nöyryyttämään ihmiseen. (Jylhänkangas 2004, 334-341). Olen kuvannut tällaista 


\section{KIPU JA KUOLEMA}

välttämättömyyksien tilassa olevaa ihmisruumista myös torjuttuna, abjektina ei-ihmisen ilmentäjänä (ks. Jylhänkangas 2001, 130-140).

8. Kulttuurisia kategorioita koskevien sääntöjen ja käsitysten turvaaminen motivoi eutanasiapuheessa kuolemaan liittyvien uskomusten tuottamista. Näitä pidetään niin tärkeinä, etteivät ihmiset voi olla niistä puhumatta. Elämän ja kuoleman välisen rajan ylittämistä koskevien uskomusten voi katsoa olevan omalla tavallaan epidemiologisia toisin sanoen alttiita uusintamiselle ja leviämiselle. Representaatioiden epidemiologiasta ks. Sperber 1996. Uskomusten epidemiologisuudesta eutanasiaan suhtautumisessa ks. Jylhänkangas 2004 ja 2001.

\section{TutKIMUSAINEISTOT}

Kirjeaineisto "Kirjoita eutanasiasta" (KE), 132 kirjettä (KE 2-133). Useissa suomalaisissa sanoma- ja aikakauslehdissä vuosina 2000-2001 julkaistujen tekijän kirjoituspyyntöjen perusteella saatu kirjeaineisto. Aineisto on tekijän hallussa.

\section{KirJallisuUs}

AHONEN, JOHANNA 2004: Sukupuolittunut ruumiillisuus, puhtaus ja saastaisuus Suomen Hare Krishna-liikkeessä. - Elore 11(2) [online]. < http://cc.joensuu.fi/ loristi/2_04/aho204.html >. [19.1.2005.]

ANTTONEN, VEIKKO 1996: Ibmisen ja maan rajat. 'Pyhä' kulttuurisena kategoriana. Suomalaisen Kirjallisuuden Seuran Toimituksia 646. Helsinki: Suomalaisen Kirjallisuuden Seura.

— 1997: Rajojen, risteysten ja anomalioiden merkitysoppia. - Teologinen aikakauskirja 102(2): 97-105.

— 1999: Elämän kääntöpuolen etnografiaa: kuolema eri uskonnoissa ja kulttuuriperinteessä. - Kuparinen, Eero (toim.), Kun aika loppuu. Kuolema historiassa. Turku: Turun yliopiston historian laitos.

— 2002: Identifying the Generative Mechanisms of Religion. - Pyysiäinen, Ilkka \& Anttonen, Veikko (eds.), Current Approaches in the Cognitive Science of Religion. London: Continuum.

ANTTONEN, VEIKKO \& VILJANEN, ANNA MARIA 2000: Mary Douglas ja ajattelun yhteisöllisyys. - Douglas, Mary, Pubtaus ja vaara. Ritualistisen rajanvedon analyysi. Tampere: Vastapaino.

BERGER, PETER \& LUCKMANN, THOMAS 1994: Todellisunden sosiaalinen rakentuminen. Tiedonsosiologinen tutkielma. Helsinki: Gaudeamus. [1966]

BOYER, PASCAL 1994: The Naturalness of Religious Ideas. A Cognitive Theory of Religion. Berkeley (CA): University of California Press.

- 2001: Religion Explained. The Evolutionary Origins of Religious Thought. New York: Basic Books. 


\section{LEILA JYLHÄNKANGAS}

DOUGLAS, MARY 1975: Implicit Meanings. Essays in Anthropology. London: Routledge \& Kegan Paul.

- 1989: Purity and Danger. An Analysis of the Concepts of Pollution and Taboo. London: Ark Paperbacks. [1966]

DURKHEIM, ÉMILE 1980: Uskontoelämän alkeismuodot. Australialainen toteemijärjestelmä. Helsinki: Tammi. [1912]

ESKOLA, JARI \& SUORANTA, JUHA 2000: Johdatus laadulliseen tutkimukseen. Tampere: Vastapaino.

ESTLANDER, ANN-MARI 2003: Kivun psykologia. Porvoo: WSOY.

FINGERROOS, OUTI 2004: Haudatut muistot. Rituaalisen kuoleman merkitykeset Kannaksen muistitiedossa. Suomalaisen Kirjallisuuden Seuran Toimituksia 985. Helsinki: Suomalaisen Kirjallisuuden Seura.

FORTES, MEYER 1979: Foreword. - Loudon, J. B. (ed.), Social Anthropology and Medicine. London: Academic Press. [1976]

GLUCKLICH, ARIEL 2001: Sacred Pain. Hurting the Body for the Sake of the Soul. Oxford: Oxford University Press.

GREENHALGH, SUSAN 2001: Under the Medical Gaze. Facts and Fictions of Chronic Pain. Berkeley: University of California Press.

HAVAS, HANNA 1994: Kipu elämän kokonaisuudessa. - Hyry, Katja (toim.), Sairaus ja ihminen. Kirjoituksia parantamisen perusteista. Tietolipas 132. Helsinki: Suomalaisen Kirjallisuuden Seura.

HONKASALO, MARJA-LIISA 1999: What is Chronic is Ambiguity. Encountering Biomedicine with Long-Lasting Pain. - Journal of the Finnish Anthropological Society 24(4): 75-92.

HOVI, TUIJA 2004: Narratiivinen näkökulma uskonnolliseen kokemukseen. Fingerroos, Outi \& Opas, Minna \& Taira, Teemu (toim.), Uskonnon paikka. Kirjoituksia uskontojen ja uskontoteorioiden rajoista. Tietolipas 205. Helsinki: Suomalaisen Kirjallisuuden Seura.

HUHTAMIES, MIKKO \& RELANDER, JUKKA 1997: Jatkettu elämä. Elinsïrtojen historia Suomessa. Helsingin yliopiston historian laitoksen julkaisuja 12. Helsinki: Helsingin yliopiston kirurgian laitos.

JEFFREY, DAVID 1993: There is Nothing More I Can Do". An Introduction to the Ethics of Palliative Care. Cornwall: Patten Press.

JYLHÄNKANGAS, LEILA 2001: Eutanasian kulttuuriset ja kognitiiviset ehdot. Argumentit elämän pybyydestä ja inhimillisen toimijan rajoista eutanasiaa koskevissa kannanotoissa. Julkaisematon uskontotieteen pro gradu -tutkielma. Turku: Turun yliopisto, uskontotiede.

- 2004: Uskonto ja kuoleminen. Elämän pyhyys ja inhimillisen toimijan rajat eutanasiaan suhtautumisessa. - Fingerroos, Outi \& Opas, Minna \& Taira, Teemu (toim.), Uskonnon paikkea. Kirjoituksia uskontojen ja uskontoteorioiden rajoista. Tietolipas 205. Helsinki: Suomalaisen Kirjallisuuden Seura.

KETOLA, KIMMO 1997: Uskonto ja kognitio. - Ketola, Kimmo et al. (toim.), Näköaloja uskontoon. Uskontotieteen ajankobtaisia sumntauksia. Helsinki: Yliopistopaino. 


\section{KIPU JA KUOLEMA}

KORHONEN, RAUNO 1994: Eutanasia - byvä kuolema ja kuolemisen vaikeus. Lapin yliopiston oikeustieteellisiä julkaisuja, sarja C: 18. Rovaniemi: Pandecta.

LAKOFF, GEORGE 1990: Women, Fire and Dangerous Things. What Categories Reveal about the Mind. Chicago: The University of Chicago Press. [1987]

LAKOFF, GEORGE \& JOHNSON, MARK 1981: Metaphors We Live By. Chicago: The University of Chicago Press. [1980]

LAWSON, E. THOMAS \& McCAULEY, ROBERT N 1990: Rethinking Religion. Connecting Cognition and Culture. Cambridge: Cambridge University Press.

LOUHIALA, PEKKA 1995: Eutanasian ongelma. - Launis, Veikko (toim.), Lääkintä-ja boitoetiikkea. Helsinki: Painatuskeskus.

MCMAHAN, JEFF 2002: The Ethics of Killing. Problems at the Margins of Life. Oxford: Oxford University Press.

METCALF, PETER \& HUNTINGTON, RICHARD 1999: Celebrations of Death. The Anthropology of Mortuary Ritual. Cambridge: Cambridge University Press. [1979] MITCHELL, BASIL 1990: The Value of Human Life. - Byrne, Peter (ed.), Medicine, Medical Ethics and the Value of Life. Chichester: John Wiley \& Sons.

MORRIS, DAVID B. 1993: The Culture of Pain. Berkeley (Calif.): University of California Press.

MORSE, JANICE M. \& JOHNSON, JOY L. 1991: Understanding the Illness Experience. - Morse, Janice M. \& Johnson, Joy L. (eds.), The Illness Experience. Dimensions of Suffering. Newbury Park: Sage.

NISSILÄ, KALERVO 1999: Saattohoidon teologia. - Teologinen Aikakauskirja 104(5): 419-427.

PAHLMAN, IRMA 2003: Potilaan itsemääräämisoikeus. Helsinki: Edita.

PENTIKÄINEN, JUHA 1968: The Nordic Dead-Child Tradition. FF Communications 202. Helsinki: Suomalainen Tiedeakatemia.

- 1990: Suomalaisen lähtö. Kirjoituksia pohjoisesta kuolemankulttuurista. Suomalaisen Kirjallisuuden Seuran Toimituksia 530. Helsinki: Suomalaisen Kirjallisuuden Seura.

PERÄKYLÄ, ANSSI 1990: Kuoleman monet kasvot. Identiteettien tuottaminen kuolevan potilaan hoidossa. Tampere: Vastapaino.

PYYSIÄINEN, ILKKA 1997: Jumalan selitys. 'Jumala' kognitiivisena kategoriana. Helsinki: Otava.

— 2001: How Religion Works. Towards a New Cognitive Science of Religion. Leiden: Brill. SALER, BENSON 2000: Conceptualizing Religion. Immanent Anthropologists, Transcendent Natives, and Unbounded Categories. New York: Berghahn Books. [1993]

SILVERMAN, DAVID 2001: Interpreting Qualitative Data. Methods for Analysing Talk, Text and Interaction. London: Sage Publications. [1993]

- 2003: Analyzing Talk and Text. - Denzin, Norman K. \& Lindoln, Yvonna (eds.), Collecting and Interpreting Qualitative Materials. Thousand Oaks (CA): Sage Publications. SOIVIO, JUHA 2004: Kärsimys, lääketiede ja toivo. Esimerkkinä sepelvaltimotaudin hoito. - Honkasalo, Marja-Liisa et al. (toim.), Arki satuttaa. Kärsimyksiä suomalaisessa nykypäivässä. Tampere: Vastapaino. 


\section{LEILA JYLHÄNKANGAS}

SPERBER, DAN 1987: On Anthropological Knowledge. Cambridge: Cambridge University Press. [1982]

- 1996: Explaining Culture: A Naturalistic Approach. Oxford: Blackwell. TEDRE, SILVA 1996: Välttämättömyyksien ruumis vanhusten hoivassa. Naistutkimus 9(4): 2-14.

TUOMAALA, SALOME 2004: Kärsimyksen rajat ja vapauden mahdollisuudet aborttipuheessa. - Honkasalo, Marja-Liisa et al. (toim.), Arki satuttaa. Kärsimyksiä suomalaisessa nykeypäivässä. Tampere: Vastapaino.

TURNER, BRYAN S. 1995: Medical Power and Social Knowledge. London: Sage.

UTRIAINEN, TERHI 1999: Läsnä, riisuttu, pubdas. Uskontoantropologinen tutkimus naisista kuoleman vierellä. Suomalaisen Kirjallisuuden Seuran Toimituksia 751. Helsinki: Suomalaisen Kirjallisuuden Seura.

— 2004: Suojaavat kehykset ja alaston kärsimys. - Honkasalo, Marja-Liisa et al. (toim.), Arki satuttaa. Kärsimykesiä suomalaisessa nykypäivässä. Tampere: Vastapaino. UTRIAINEN, TERHI \& HONKASALO, MARJA-LIISA 2004: Kärsimys, paha ja kulttuurintutkimus. - Honkasalo, Marja-Liisa et al. (toim.), Arki satuttaa. Kärsimyksiä suomalaisessa nykeypäivässä. Tampere: Vastapaino.

VAINIO, ANNELI 1993: Inbimillinen kuolema. Saattohoito Suomessa. Saattohoidon, palliatiivisen hoidon ja tukihoidon analyysia. Helsinki: Sairaalaliitto. 


\section{LIITTEET}

Liite 1

Kirjoita eutanasiasta

Olen tekemässä Turun yliopistoon pro gradu -tutkielmaa eutanasiaan liittyvistä mielipiteistä. Eutanasialla tarkoitetaan yleensä lääkärin tarkoituksellisesti aiheuttamaa potilaan kuolemaa tämän nimenomaisesta pyynnöstä. Olisin kiitollinen, jos asiasta kiinnostuneet kirjoittaisivat minulle näkemyksiään (esim. tulisiko eutanasia sallia vai ei? Miksi?). Voit kirjoittaa myös sähköpostitse. Käsittelen vastaukset ehdottoman luottamuksellisesti.

Leila Jylhänkangas, fil.yo

Osoite

e-mail

Liite 2

Kirjoita eutanasiasta

Olen tekemässä Turun yliopistoon pro gradu -tutkielmaa eutanasiaan liittyvistä mielipiteistä. Mitä eutanasialla mielestäsi tarkoitetaan? Tulisiko eutanasia sallia vai ei? Miksi? Olisin kiitollinen, jos asiasta kiinnostuneet kirjoittaisivat minulle näkemyksiään. Voit kirjoittaa myös sähköpostitse. Käsittelen vastaukset ehdottoman luottamuksellisesti.

Leila Jylhänkangas, fil.yo

Osoite

e-mail

Leilä Jylhänkangas (FM) on uskontotieteen tutkija Turun yliopistossa ja valmistelee väitöskirjaa aiheesta Eutanasiaan suhtautumisen kulttuuriset ulottuvuudet Suomessa. 